\title{
Nutritional value of protein in wheat-rye bread manufactured with addition of flour from low-alkaloid cultivars of lupin
}

\section{Jan Kłobukowski ${ }^{1}$, Marzena Danowska-Oziewicz ${ }^{1}$, Filip Kłobukowski ${ }^{2}$, Krystyna Skibniewska ${ }^{1}$}

\author{
1 - University of Warmia and Mazury in Olsztyn, Olsztyn, Poland \\ 2 - Medical University of Gdańsk, Gdańsk, Poland
}

Keywords:

Bread

Lupin

Protein

Digestibility

\section{Article history:}

Received 18.10.2020

Received in revised

form 26.04.2021

Accepted 30.06.2021

\section{Corresponding}

author:

Jan Kłobukowski

E-mail:

jan.klobukowski@

uwm.edu.pl

DOI: $10.24263 / 2304-$

974X-2021-10-2-4

\section{Abstract}

Introduction. The aim of this study was to assess the nutritional value of protein in wheat-rye bread manufactured with an addition of flour from low-alkaloid cultivars of lupin.

Material and methods. Flours from yellow lupin cultivars: Juno, Polo, Legat and Markiz, were used in wheat-rye bread baking. The following were determined in breads: protein content, in vitro protein digestibility, amino acid composition, effective protein content (EP), chemical score (CS), essential amino acid index (EAAI), true digestibility of protein (TD), protein digestibility corrected amino acid score (PDCAAS) and protein efficiency ratio (PER).

Results and discussion. The addition of lupin flour resulted in an increase in the total protein and digestible protein in breads. The greatest increase in the EP, CS, PDCAAS and EAAI was observed when the bread was enriched with flour from Polo cultivar. No significant changes were noted in PER. Protein in the products with lupin flour contained more leucine, lysine, asparagine and arginine, than the cotrol sample. A tendency has been recently observed to enrich cereal products, mainly those made from wheat and wheat-rye mixes, with flours obtained from other plants, such as lupin, green peas, beans, hemp and buckwheat. These flours are highly valued because of their functional properties, which include solubility, emulsifying capabilities, foaming and gelling properties, and water retaining capability. Lupin flour and protein isolates from lupin seeds does not affect the taste of a final product. An addition of lupin flour to wheat bread improves considerably the quality and amount of protein and dietary fibre in a final product. The high values of indices PDCAAS and PER make it possible to compare lupin proteins and proteins of leguminous plants to animal proteins.

Conclusions. Protein of low-alkaloid cultivars of lupin can be a valuable component which increases the nutritional value of bread protein and therefore it should be recommended for use in baking. 


\section{- Food Technology -}

\section{Introduction}

Cereal products, including bread, are at the base of many present food pyramids. They provide the human body with energy, protein of plant origin, vitamins B as well as macronutrients (magnesium, potassium, phosphorus) and micronutrients (iron, copper). Protein performs a number of functions in the body, with serving as building blocks being the most important of them. However, cereal proteins are regarded as having lower biological value than those of animal origin. This is because they contain, depending on the cereal species, smaller amounts of some essential amino acids - lysine and tryptophan (wheat and maize), methionine (rye) and threonine (rice) (Hryniewiecki, 2007).

Leguminous plants, particularly soybean, are used as a raw material in the production of food which provides the body with full-value protein. Lupin is an alternative source of protein, which can replace soybean imported from the warm climate zone. The use and consumption of products from seeds of this plant have been steadily growing in recent years (De Cortes-Sanchez et al., 2005). Lupin is a good source not only of protein and essential amino acids, but also of fat, dietary fibre, minerals and vitamins (Martinez-Villaluenga et al., 2006, 2009; Zielińska et al., 2008; Kohajdoova et al., 2011; Schumacher et al., 2011). Due to a high content of lysine in lupin protein, particularly in "sweet", low-alkaloid cultivars, it can be an excellent supplement of cereal proteins, in which the content of this amino acid is low.

In the current available literature, no data on the usefulness of the protein of bread baked from wheat-rye flour enriched with lupine flour have been found. It was decided that the nutritional value of the protein of the analyzed bread should, apart from traditional chemical quality indicators, be extended with the newest, recommended indicators taking into account the biological availability of this nutrient.

The aim of this study was to assess the nutritional value of protein in wheat-rye bread manufactured with an addition of flour from low-alkaloid cultivars of lupin.

\section{Materials and methods}

\section{Sample preparation}

Bread made from the mixture of wheat-rye $(80: 20)$ flours $(\mathrm{K}$ - control) and breads from wheat-rye flour with a $5 \%$ addition of flour from four low-alkaloid "sweet" cultivars of yellow lupin $(75: 20: 5)$ were used as the study material. The experimental breads were marked after cultivars as: $\mathbf{J}$ - Juno, P - Polo, L - Legat, and M - Markiz. Lupin seeds were obtained from the Agricultural Experiment Unit of the University of Warmia and Mazury in Olsztyn, Poland. The bread was baked in a private bakery. The baking process was carried out as described in Skibniewska et al. (2003).

\section{Analyses}

The total protein $(\mathrm{N} \times 6.25)$ was determined according to AOAC (1995a). The in vitro protein digestibility, i.e. its susceptibility to the action of digestive enzymes, was determined after incubation with a solution of pepsin, pancreatin and a bile extract at the enzyme-protein ratio of $1: 20$ (Ikeda, 1990). The in vitro protein digestibility was calculated from the following formula: $\left(D_{\text {in vitro }}=[a-b / a] \times 100\right)$, where $a-$ starting content of protein in the 


\section{- Food Technology —}

bread under study as $\mathrm{g} / 100 \mathrm{~g}$ of bread, $\mathrm{b}$ - content of protein in the bread under study following in vitro digestion, as $\mathrm{g} / 100 \mathrm{~g}$ of bread.

Amino acid content (g/16 g N, equivalent of $\mathrm{g} / 100 \mathrm{~g}$ of protein) was determined with an amino acid analyser Biochrom 20 Plus (Biochrom Ltd., Cambridge, UK). The Amino Acid Standard Solution by Sigma was used as the standard. The protein hydrolysate was prepared by acidic hydrolysis $\left(6 \mathrm{M} \mathrm{HCl}\right.$, at $105^{\circ} \mathrm{C}$ for $24 \mathrm{~h}$ ). The content of sulphur amino acids was determined separately in $6 \mathrm{M} \mathrm{HCl}$ following oxidative hydrolysis (formic acid + hydrogen peroxide at $9: 1$ ratio, $4^{\circ} \mathrm{C}, 16 \mathrm{~h}$ ). Tryptophan was determined according to AOAC (1995b).

The content of essential amino acids in the breads under study was used as the basis for calculation of the chemical protein quality indices: the chemical score (CS) and the integrated essential amino acid index (EAAI). The amino acid composition of two standard proteins - FAO/WHO 1991 and DRI/USA 2005 (Jarosz et. al., 2017) was used in the calculations. The CS index was calculated from the formula: $X_{i}=a_{i} / a_{i s} \times 100$, where $a_{i}-$ the content of a given essential amino acid in the protein under test, $\mathrm{a}_{\mathrm{is}}$ - the content of a given essential amino acid in the standard protein, $i=1,2 \ldots 8$ (Hryniewiecki, 2007). The calculations were conducted using the content of isoleucine (ILEU), leucine (LEU), lysine (LYS), sum of methionine and cysteine (MET + CYS), phenylalanine and tyrosine (PHE + TYR), threonine (THR), tryptophan (TRY) and valine (VAL). The CS is taken as the lowest $\left(\mathrm{X}_{\text {min. }}\right)$ of the eight ratios expressed as percent $\left(\mathrm{X}_{\min .}=\mathrm{CS}\right)$, and the amino acid for which the value is the lowest is the one limiting the nutritional value of the protein.

The EAAI, introduced by Oser (1959), was calculated from the formula:

$$
\mathrm{EAAI}=10^{\lg \mathrm{EAA}} \text {. }
$$

In order to calculate $\lg$ EAA, the following formula, provided by Rakowska et al. (1978), was used:

$$
\lg \mathrm{EAA}=1 / 8\left(\lg \mathrm{X}_{1}+\lg \mathrm{X}_{2}+\ldots+\lg \mathrm{X}_{8}\right)
$$

The content of effective protein (EP) was calculated from the respective CS (\%) and the total protein content (TP, \%) in the bread under analysis, from the following formula:

$$
\mathrm{EP}(\%)=\mathrm{TP} \times \mathrm{CS} / 100 \text { (Gawęcki \& Jeszka, 1986). }
$$

The true digestibility (TD, \%) of investigated bread samples was calculated as the weighted average of the true digestibility indices of individual components of breads and their percentage share. The TD values of individual components were taken after Boye et al. (2012): wheat flour $-89.4 \%$, rye flour (barley) $-75.3 \%$, lupin flour (soybean) $-80.0 \%$.

The protein digestibility corrected amino acid score (PDCAAS) was calculated from the formula:

$$
\text { PDCAAS }(\%)=\text { CS }(\%) \times \text { TD }(\%) / 100(\text { Schaafsma, 2012, Ruhterfurd 2015). }
$$


The protein efficiency ratio (PER) was calculated from the content $(\mathrm{g} / 16 \mathrm{~g} \mathrm{~N})$ of leucine (LEU) and tyrosine (TYR) in the bread from the following formula:

$$
\text { PER }=-0.468+0.454 \mathrm{LEU}-0.105 \text { TYR (Sujak et al., 2006). }
$$

The chemical analyses were performed in triplicates. The results in Table 1 and 2 are presented as mean values with standard deviations. The statistical significance of differences between the mean values was tested with the Student's t-test at the significance level of $P \leq$ 0.05, using the Statistica PL 10.0 software (StatSoft, Kraków, Poland).

\section{Results and discussion}

\section{Protein content and in vitro protein digestibility in the breads under study}

Table 1 shows the protein content and its in vitro digestibility in the tested samples. All breads manufactured with the addition of lupin flour contained more protein $(10.1-11.0 \%)$ than the control bread (9.0\%), with the bread enriched with the Markiz cultivar flour showing the highest percentage of protein. No significant differences were observed between the breads made with an addition of lupin flours. The content of protein following in vitro digestion was the highest in bread prepared with an addition of flour from the Juno $(5.6 \%)$ cultivar, but again, no statistical differences between the enriched breads were observed. All values of this parameter were higher in the experimental samples than in the control. The protein in the bread enriched with the Juno cultivar was the most susceptible to the action of digestive enzymes $(55.4 \%)$. The other digestibility indices were not statistically different and were $50.5 \% ; 49.1 \%$ and $49.1 \%$ for breads with flours of the Polo, Legat and Markiz cultivars, respectively.

Table 1

Protein content and in vitro protein digestibility in the breads under study $($ mean \pm SD)

\begin{tabular}{|l|c|c|c|c|c|}
\hline \multirow{2}{*}{ Specification } & \multicolumn{4}{|c|}{ Type of bread } \\
\cline { 2 - 6 } & $\begin{array}{c}\text { Control } \\
\text { K }\end{array}$ & $\begin{array}{c}\text { Juno } \\
\text { J }\end{array}$ & $\begin{array}{c}\text { Polo } \\
\text { P }\end{array}$ & $\begin{array}{c}\text { Legat } \\
\text { L }\end{array}$ & $\begin{array}{c}\text { Markiz } \\
\text { M }\end{array}$ \\
\hline $\begin{array}{l}\text { Total protein content, } \\
\text { g/100 g }\end{array}$ & $9.0 \pm 0.2^{\mathrm{a}}$ & $10.1 \pm 0.2^{\mathrm{b}}$ & $10.5 \pm 0.2^{\mathrm{b}}$ & $10.8 \pm 0.2^{\mathrm{b}}$ & $11.0 \pm 0.3^{\mathrm{b}}$ \\
$\begin{array}{l}\text { Protein content following } \\
\text { in vitro digestion, g/100 g } \\
\begin{array}{l}\text { In vitro protein } \\
\text { digestibility, \% }\end{array}\end{array}$ & $4.4 \pm 0.1^{\mathrm{a}}$ & $5.6 \pm 0.1^{\mathrm{b}}$ & $5.3 \pm 0.3^{\mathrm{b}}$ & $5.3 \pm 0.1^{\mathrm{b}}$ & $5.3 \pm 0.3^{\mathrm{b}}$ \\
\hline
\end{tabular}

Different letters in a row denote the presence of differences statistically significant at $P \leq 0.05$ 


\section{Amino acid composition of wheat-rye bread made with an addition of selected lupin flours}

Table 2 presents the content of amino acids in protein of the investigated bread samples. Modification of the dough composition significantly increased the content of leucine level from $7.4 \mathrm{~g} / 16 \mathrm{~g} \mathrm{~N}$ in the control sample to $7.7 \mathrm{~g} / 16 \mathrm{~g} \mathrm{~N}$ in the bread with

an addition of flour from the Legat cultivar. Nevertheless, the content of this amino acid in all investigated breads exceeds its content in the standard protein FAO/WHO 1991 (6.6 $\mathrm{g} / 16 \mathrm{~g} \mathrm{~N})$ and DRI/USA 2005 (5.5 g/16 $\mathrm{g} \mathrm{N})$.

Table 2

Amino acid composition of wheat-rye bread made with an addition of selected lupin flours $($ mean \pm SD)

\begin{tabular}{|c|c|c|c|c|c|}
\hline \multirow[b]{2}{*}{ Specification } & \multicolumn{5}{|c|}{ Type of bread } \\
\hline & $\begin{array}{c}\text { Control } \\
\mathrm{K}\end{array}$ & $\begin{array}{c}\text { Juno } \\
\text { J }\end{array}$ & $\begin{array}{c}\text { Polo } \\
\text { P }\end{array}$ & $\begin{array}{c}\text { Legat } \\
\text { L }\end{array}$ & $\begin{array}{c}\text { Markiz } \\
\text { M }\end{array}$ \\
\hline \multicolumn{6}{|l|}{$\begin{array}{l}\text { Essential amino acids, } \\
\text { g/16 g N }\end{array}$} \\
\hline \multirow{8}{*}{$\begin{array}{l}\text { Thr } \\
\text { Met } \\
\text { Met + Cys } \\
\text { Val } \\
\text { Ileu } \\
\text { Leu } \\
\text { Phe } \\
\text { Phe + Tyr }\end{array}$} & $2.9 \pm 0.1^{\mathrm{a}}$ & $3.0 \pm 0.1^{\mathrm{a}}$ & $2.8 \pm 0.1^{\mathrm{a}}$ & $2.9 \pm 0.1^{\mathrm{a}}$ & $2.9 \pm 0.2^{\mathrm{a}}$ \\
\hline & $2.1 \pm 0.1^{\mathrm{a}}$ & $1.7 \pm 0.1^{\mathrm{b}}$ & $1.8 \pm 0.1^{\mathrm{ab}}$ & $1.9 \pm 0.1^{\mathrm{a}}$ & $1.7 \pm 0.2^{\mathrm{ab}}$ \\
\hline & $3.5 \pm 0.1^{\mathrm{a}}$ & $3.2 \pm 0.1^{\mathrm{b}}$ & $3.3 \pm 0.1^{\mathrm{ab}}$ & $3.1 \pm 0.1^{\mathrm{b}}$ & $3.1 \pm 0.3^{\mathrm{ab}}$ \\
\hline & $5.4 \pm 0.1^{\mathrm{a}}$ & $5.2 \pm 0.1^{\mathrm{a}}$ & $5.2 \pm 0.1^{\mathrm{a}}$ & $5.3 \pm 0.1^{\mathrm{a}}$ & $5.1 \pm 0.3^{\mathrm{a}}$ \\
\hline & $4.2 \pm 0.1^{\mathrm{a}}$ & $4.3 \pm 0.1^{\mathrm{a}}$ & $4.1 \pm 0.1^{\mathrm{a}}$ & $4.3 \pm 0.1^{\mathrm{a}}$ & $4.2 \pm 0.1^{\mathrm{a}}$ \\
\hline & $7.4 \pm 0.1^{\mathrm{a}}$ & $7.5 \pm 0.1^{\mathrm{a}}$ & $7.4 \pm 0.1^{\mathrm{a}}$ & $7.7 \pm 0.1^{\mathrm{b}}$ & $7.6 \pm 0.3^{\mathrm{ab}}$ \\
\hline & $5.3 \pm 0.1^{\mathrm{a}}$ & $5.0 \pm 0.1^{\mathrm{b}}$ & $4.9 \pm 0.1^{\mathrm{b}}$ & $4.9 \pm 0.1^{\mathrm{b}}$ & $5.2 \pm 0.1^{\mathrm{a}}$ \\
\hline & $7.3 \pm 0.2^{\mathrm{a}}$ & $7.0 \pm 0.1^{\mathrm{a}}$ & $6.9 \pm 0.1^{\mathrm{a}}$ & $7.3 \pm 0.1^{\mathrm{a}}$ & $7.2 \pm 0.3^{\mathrm{a}}$ \\
\hline \multirow{3}{*}{$\begin{array}{c}\text { Lys } \\
\text { Try } \\
\text { Non-essential amino } \\
\text { acids, g/16 g } \mathbf{~ N}\end{array}$} & $2.5 \pm 0.1^{\mathrm{a}}$ & $3.2 \pm 0.1^{\mathrm{b}}$ & $3.7 \pm 0.1^{b}$ & $2.9 \pm 0.1^{\mathrm{b}}$ & $3.0 \pm 0.3^{b}$ \\
\hline & $0.8 \pm 0.1^{\mathrm{a}}$ & $0.8 \pm 0.1^{\mathrm{a}}$ & $0.8 \pm 0.1^{\mathrm{a}}$ & $0.8 \pm 0.1^{\mathrm{a}}$ & $0.8 \pm 0.1^{\mathrm{a}}$ \\
\hline & & & & & \\
\hline \multirow{8}{*}{$\begin{array}{l}\text { Asp } \\
\text { Ser } \\
\text { Glu } \\
\text { Pro } \\
\text { Ala } \\
\text { Gli } \\
\text { His } \\
\text { Arg }\end{array}$} & $4.4 \pm 0.1^{\mathrm{a}}$ & $5.3 \pm 0.2^{\mathrm{b}}$ & $5.3 \pm 0.2^{b}$ & $5.2 \pm 0.1^{\mathrm{b}}$ & $5.3 \pm 0.2^{b}$ \\
\hline & $4.6 \pm 0.1^{\mathrm{a}}$ & $4.5 \pm 0.1^{\mathrm{b}}$ & $4.5 \pm 0.1^{\mathrm{b}}$ & $4.6 \pm 0.1^{\mathrm{a}}$ & $4.4 \pm 0.3^{\mathrm{ab}}$ \\
\hline & $33.0 \pm 0.1^{\mathrm{a}}$ & $32.1 \pm 0.1^{\mathrm{b}}$ & $31.8 \pm 0.1^{\mathrm{b}}$ & $31.5 \pm 0.5^{b}$ & $32.0 \pm 0.2^{\mathrm{ab}}$ \\
\hline & $11.3 \pm 0.1^{\mathrm{a}}$ & $9.7 \pm 0.1^{\mathrm{b}}$ & $9.5 \pm 0.1^{b}$ & $9.7 \pm 0.1^{\mathrm{b}}$ & $9.9 \pm 0.4^{b}$ \\
\hline & $3.4 \pm 0.1^{\mathrm{a}}$ & $3.4 \pm 0.1^{\mathrm{a}}$ & $3.6 \pm 0.1^{b}$ & $3.5 \pm 0.2^{\mathrm{a}}$ & $3.4 \pm 0.2^{\mathrm{a}}$ \\
\hline & $3.6 \pm 0.1^{\mathrm{a}}$ & $3.6 \pm 0.2^{\mathrm{a}}$ & $3.6 \pm 0.2^{\mathrm{a}}$ & $3.6 \pm 0.1^{\mathrm{a}}$ & $3.7 \pm 0.1^{\mathrm{a}}$ \\
\hline & $2.0 \pm 0.1^{\mathrm{a}}$ & $2.0 \pm 0.1^{\mathrm{a}}$ & $2.2 \pm 0.1^{\mathrm{b}}$ & $2.1 \pm 0.1^{\mathrm{a}}$ & $2.2 \pm 0.3^{\mathrm{a}}$ \\
\hline & $3.5 \pm 0.1^{\mathrm{a}}$ & $5.0 \pm 0.5^{\mathrm{b}}$ & $5.0 \pm 0.1^{\mathrm{b}}$ & $4.7 \pm 0.1^{\mathrm{b}}$ & $4.8 \pm 0.2^{\mathrm{b}}$ \\
\hline
\end{tabular}

Different letters in a row denote the presence of differences statistically significant at $P \leq 0.05$

Particular improvement of the protein quality in breads with the addition of lupin flour was observed in the case of lysine. Bread with the flour from the Juno cultivar contained 3.2 $\mathrm{g} / 16 \mathrm{~g} \mathrm{~N}$ of lysine, that with an addition of the Polo cultivar $-3.7 \mathrm{~g} / 16 \mathrm{~g} \mathrm{~N}$; Legat $-2.9 \mathrm{~g} / 16$ $\mathrm{g} \mathrm{N}$, and Markiz - $3.0 \mathrm{~g} / 16 \mathrm{~g} \mathrm{~N}$. The content of lysine in protein of the control sample was 
$2.5 \mathrm{~g} / 16 \mathrm{~g} \mathrm{~N}$. Regarding the non-essential amino acids, a considerable increase in the amount of asparagine was recorded in all breads enriched with lupin flour: Juno $-5.3 \mathrm{~g} / 16 \mathrm{~g} \mathrm{~N}$, Polo $-5.3 \mathrm{~g} / 16 \mathrm{~g} \mathrm{~N}$, Legat $-5.2 \mathrm{~g} / 16 \mathrm{~g} \mathrm{~N}$ and Markiz $-5.3 \mathrm{~g} / 16 \mathrm{~g} \mathrm{~N}$, compared to the control sample $(4.4 \mathrm{~g} / 16 \mathrm{~g} \mathrm{~N})$. An addition of flour of the Polo cultivar increased the content of alanine in the protein from $3.4 \mathrm{~g} / 16 \mathrm{~g} / \mathrm{N}$ (control bread) to $3.6 \mathrm{~g} / 16 \mathrm{~g} \mathrm{~N}$. The content of arginine increased considerably in each option of the bread enrichment with lupin flour. It was $5.0 ; 5.0 ; 4.7 ; 4.8 \mathrm{~g} / 16 \mathrm{~g} \mathrm{~N}$ for the breads with the addition of flour from the Juno, Polo, Legat and Markiz cultivars, respectively, compared to the control sample $-3.5 \mathrm{~g} / 16 \mathrm{~g} \mathrm{~N}$. Conversely, all breads enriched with lupin flour contained considerably less methionine + cystine, while valine and phenylalanine + tyrosine remained at the comparable level to protein in the bread made from wheat and rye flour (Table 2).

\section{Chemical and dietary indices of the protein nutritional value of wheat-rye bread made with selected lupin flours}

The chemical and dietary indices of the nutritional value of protein were calculated using two amino acid standards - FAO/WHO 1991 and DRI/USA 2005 (Table 3). The content of effective protein (EP) increased after the addition of lupin flour from each cultivar under study, and it was the highest when the bread was enriched with flour from the Polo cultivar. The values obtained for this sample with the use of both of the standards were 6.7\% and $7.6 \%$, respectively. The addition of lupin flour increased the chemical score and the essential amino acid index of all investigated samples. Lysine was the limiting amino acid in each treatment. The highest CS was calculated when flour from the Polo cultivar was added $(63.8 \% ; 72.5 \%)$, likewise an increase in the EAAI calculated on the base of the FAO/WHO 1991 standard (104.7\%). The highest EAAI was observed for the bread prepared with flour from the Markiz cultivar, when calculations were based on the DRI/USA 2005 standard $(128.8 \%)$. The true digestibility of protein was slightly lower in all lupin enriched samples $(86.2 \%)$ than in the control $(86.6 \%)$. The PDCAAS increased considerably in the samples under analysis compared to the values calculated for the bread without the addition of lupin flour $(37.3 \%$; 42.4\%). The largest increase was observed when flour from the Polo cultivar was added $(55.0 \% ; 62.5 \%)$. Similar values of the PER were calculated for the bread with the addition of flour from the Juno (2.73), Legat (2.75) and Markiz (2.77) cultivars, whereas the value for the bread with the addition of flour from the Polo cultivar was the same as for the bread from wheat-rye flour -2.68 (Table 3 ).

Starvation, malnutrition and insufficient supply of nutrients are the problems that the contemporary world struggles with. There is a significant demand for food products of high nutritional value, obtained from stable and sustainable sources (Raikos et al., 2014).

Staple foods in the majority of countries are breads of different kinds and other products made from flour. In general, one can claim that bread is the basic food, although its forms can be different in different cultures. Bakery products are made mainly from wheat flour. This material is highly valued because of its versatile physical and chemical properties, and the possibility of use in manufacturing many food products. 
Table 3

Chemical and dietary indices of the protein nutritional value of wheat-rye bread made with selected lupin flours

\begin{tabular}{|c|c|c|c|c|c|}
\hline \multirow[b]{2}{*}{ Specification } & \multicolumn{5}{|c|}{ Type of bread } \\
\hline & $\begin{array}{c}\text { Control } \\
\mathrm{K}\end{array}$ & Juno & $\begin{array}{c}\text { Polo } \\
\text { P }\end{array}$ & $\begin{array}{c}\text { Legat } \\
\text { L }\end{array}$ & $\underset{\mathbf{M}}{\text { Markiz }}$ \\
\hline $\mathrm{EP}^{1}, \%$ & 3.9 & 5.6 & 6.7 & 5.4 & 5.7 \\
\hline $\mathrm{EP}^{2}, \%$ & 4.4 & 6.3 & 7.6 & 6.1 & 6.5 \\
\hline $\mathrm{CS}^{1}, \%$ & 43.1 & 55.2 & 63.8 & 50.0 & 51.7 \\
\hline Limiting amino acid ${ }^{1}$ & Lys & Lys & Lys & Lys & Lys \\
\hline $\mathrm{CS}^{2}, \%$ & 49.0 & 62.7 & 72.5 & 56.7 & 58.8 \\
\hline Limiting amino acid $^{2}$ & Lys & Lys & Lys & Lys & Lys \\
\hline $\mathrm{EAAI}^{1}, \%$ & 100.0 & 102.3 & 104.7 & 102.3 & 102.3 \\
\hline $\mathrm{EAAI}^{2}, \%$ & 123.0 & 120.2 & 125.9 & 123.0 & 128.8 \\
\hline $\mathrm{TD}, \%$ & 86.6 & 86.2 & 86.2 & 86.2 & 86.2 \\
\hline $\operatorname{PDCAAS}^{1}, \%$ & 37.3 & 47.6 & 55.0 & 43.1 & 44.6 \\
\hline PDCAAS $^{2}, \%$ & 42.4 & 54.0 & 62.5 & 48.9 & 50.7 \\
\hline PER & 2.68 & 2.73 & 2.68 & 2.75 & 2.77 \\
\hline
\end{tabular}

${ }^{1}$ Chemical indices of nutritional value of protein calculated on the basis of the amino acid standard FAO/WHO 1991.

${ }^{2}$ Chemical indices of nutritional value of protein calculated on the basis of the amino acid standard DRI/USA 2005

$\mathrm{EP}$ - effective protein; $\mathrm{CS}$ - chemical score; EAAI - integrated essential amino acid index; TD - true digestibility; PDCAAS - protein digestibility corrected amino acid score; PER - protein efficiency ratio

\section{Discussion}

A tendency has been recently observed to enrich cereal products, mainly those made from wheat and wheat-rye mixes, with flours obtained from other plants, such as lupin, green peas, beans, hemp and buckwheat. These flours are highly valued because of their functional properties, which include solubility, emulsifying capabilities, foaming and gelling properties, and water retaining capability (Raikos et al., 2014). Economic, environmental and healthrelated factors play an important role in seeking new solutions and combinations in bakery. They include prices increase on the food market, the need to ensure supplies from stable and so far unused sources and preventing protein undernourishment. The last factor is a common 
problem in developing and economically backward countries due to restricted access to animal protein (Bhat \& Karim, 2009). With this issue in mind, the present study focuses on the usability of lupin in a form of flour in bread baking as an opportunity to improve the nutritional value of protein contained in this food product. Since bread, in its various forms, is highly valued around the world owing to its sensory properties, readiness to be consumed and, importantly, because of its price, one can claim that it is eaten by all social groups (Correia et al., 2015). Therefore, improving the quality of protein consumed with this product can contribute to the considerable improvement of nourishment of many people.

The present study has demonstrated an alteration of the quality of protein in the wheatrye bread prepared with an addition of flour from different lupin cultivars. An addition of lupin flour itself contributed to an increase in the total protein content in the product (Table 1). Lupin seeds have been consumed since antiquity but, apart from being used as food, they have many other applications (EFSA 2005). Interestingly, a 5\% addition of lupin flour from sweet lupin cultivars has a positive effect on the organoleptic properties of bread and it delays the process of bread staling (Skibniewska et al. 2003). An addition of $10 \%$ lupin flour to bread generates a product with slightly different physical and chemical properties. These include rheological properties of dough, its density, colour and texture. It is encouraging that the consumer sensory assessment showed that the differences originating from the enrichment with lupin flour are practically imperceptible, which makes it possible to improve the nutritional quality without changing the product features, which mainly affect the consumers' choices (Correia et al., 2015). Lupin flour and protein isolates from lupin seeds are widely used in creating new food products because their addition does not affect the taste of a final product (Gresta et al., 2017). Studies have shown that an addition of lupin flour to wheat bread improves considerably the quality and amount of protein and dietary fibre in a final product. The growing interest in the use of lupin seeds in the global food production is also caused by the fact that it is not a genetically modified plant and it contains less phytoestrogens than soybean, and also that lupin flour provides less calories than refined wheat flour (Hall \& Johnson, 2004; Villarino et al., 2015a). Lupin seeds are rich in carotenoids, phenols and have high antioxidant potential (Siger et al., 2012). In Arab countries, flour from seeds of leguminous plants is used to improve the nutritional value of pita bread (traditionally made from wheat flour), because of a low level of lysine and a relatively high level of sulphur amino acids in wheat protein (Mubarak, 2001; Abu-Ghoush et al., 2008). Moreover, enriching Arab bread with lupin flour has contributed to an increase in the content of total ash, dietary fibre, total fat and a decrease in carbohydrates content (Al Omari et al., 2015). Lysine was the limiting amino acid in the protein of the wheat-rye bread under study. The chemical score increased after the addition of lupin flour, by even $25 \%$ in the case of the Polo cultivar (Table 3). Lupin protein is described as complementary and it perfectly supplements the diet with essential amino acids (Lampart-Szczapa et al., 2003; Erbas et al., 2005). Their content is estimated to be higher than in soybean and regarded as a perfect substitute of animal protein (Süssmann et al., 2007). However, although European consumers express positive opinions on the consumption of plant protein, they are largely unaware that lupin seeds are not inferior to soybean in this regard (Lucas et al., 2015). Lupin is an alternative to soybean in the production of fermented foods, such as Indonesian tempeh, Japanese miso and natto, and fermented spices (Rybiński et al., 2018). Inclusion of lupin in the human diet also brings other benefits than just the quality of protein. Studies have confirmed the positive effect of the consumption of lupin flours in diabetes because of the presence of dietary fibre, and the properties which reduce the risk of coronary disease owing to the presence of agents which decrease the blood lipid and sugar levels (Duranti, 2006; Rumiyati et al., 2012; Rumiyati et al., 2015; Tadele, 2015). Currently, lupin seeds, flour and 
bran are used in Europe to enrich breads, pasta, cakes, muffins as well as extruded snacks and beverages. Lupin is also widely used in production of gluten-free food. Lupin germs are eaten in Australia. White lupin grown in Ethiopia under the local name of "Gibto" is baked and then used as raw material in production of alcoholic beverage called "Arekie". It is also used as a snack or a condiment called "Shiro" (Tizazu \& Emire, 2010; Yeheis et al., 2010). Efforts have also been made to replace animal and soy protein with lupin seeds in feeding pigs and broilers, which would have a beneficial effect on the fatty acid profile of pork and poultry (Zraly et al., 2007; Mierlita 2015).

The dietetic role of lupin has been confirmed in studies on the possibility of effective regulation of appetite owing to an addition of lupin flour to wheat bread. Forty percent of wheat flour used to make dough was replaced with lupin flour. Analyses have revealed more than two-fold increase in the total protein content in bread with an addition of lupin compared to wheat bread, with an unchanged amount of total fat. Moreover, the amount of fibre increased almost four-fold. Bread with an addition of lupin flour was a rich source of protein and fibre, which partly replaced carbohydrates from wheat flour. The amount of carbohydrates was found to decrease by $30 \%$. Consumption of bread enriched with lupin flour resulted in an increased feeling of satiety and lower (by approx. 20\%) intake of energy in next meals. It affected secretion of ghrelin, glucose and insulin after a meal. This experiment has confirmed that the consumption of high protein diet rich in fibre reduces energy intake in subsequent meals more than consumption of high-carbohydrate diets (Lee et al., 2006). Food enriching with lupin can be useful in treatment and prevention of obesity as well as some diseases caused by this state. As has been noted earlier in the present study, an addition of lupin flour to wheat-rye bread resulted in a considerable increase in the amount of arginine in the protein, regardless of which cultivar of lupin was used. A high content of arginine is typical of all lupin cultivars. This amino acid plays a key role in regulating lipid content in blood. A study conducted by Bähr et al. (2015) showed that consumption of products enriched with lupin protein (bread, sausages, vegetarian pâtés) has a beneficial effect on the blood lipid profile, in the same way as the consumption of products enriched with milk protein with an elevated concentration of arginine. Food enriched with lupin is said to have a nutraceutical potential, so it has a positive effect on human health in the treatment and prevention of diseases. Apart from these benefits, lupin proteins are known to decrease the sugar level in blood. It has been demonstrated that lupin protein extract is 10 times more potent than standard anti-diabetic drugs (Agrawal et al., 2015). The main interest is focused on gamma-conglutin, which accounts for approx. 5\% of all lupin seed proteins and which plays a role in the plants' defence against pathogens (Agizzio et al., 2003). This bioactive peptide has not been found in bread made exclusively from refined wheat flour. In addition, such benefits like the facilitation of defecation and blood pressure decrease have been mentioned. Arginine is a precursor of the synthesis of nitrogen oxide. The mechanism of blood pressure decrease may involve relaxation of the blood vessel walls by nitrogen oxide, which is a potent endothelium relaxing factor (Sedlakova et al., 2016). Other examples of bioactive lupin proteins include serine protease of the Bowman-Birk type, whose beneficial effect has been demonstrated in cancers, atrophy of skeletal muscles, angiogenesis, rheumatoid arthritis, neurodegenerative diseases and coronary disease treatments (Scarafoni et al., 2008).

In the present study, the addition of lupin flour to wheat-rye bread considerably improved its in vitro digestibility (Table 1) and increased the PDCAAS (Table 3). A positive effect of the addition of flour from leguminous plants to wheat sourdough breads and glutenfree cakes on in vitro digestibility of proteins in the final product has been observed (Anyango et al., 2011; Gularte et al., 2012). Studies have shown that 5\% addition of lupin flour 
increases the PDCAAS by 15 to approx. $50 \%$, depending on the lupin cultivar used. The findings of Villarino et al. (2015b) indicate that a $20 \%$ addition of lupin flour from various cultivars of narrow leaf lupin (Lupinus angustifolius, ASL) increases the PDCAAS by approx. 50\%, regardless of the cultivar used. Such high values of these indices make it possible to compare lupin proteins and proteins of leguminous plants to animal proteins (Erbersdobler et al., 2017a,b).

The effect of enriching bread with lupin flour on the protein efficiency ratio proved insignificant for all the lupin cultivars under study. The findings of animal studies presented by Monteiro et al. (2014) were similar and were indicative of a much greater effect of supplementation with casein on the PER.

\title{
Conclusions
}

The addition of lupin flour to wheat-rye bread resulted in an increase in total and digestible protein in the final product, regardless of the lupin cultivar used. Enrichment of wheat-rye flour with lupin flour from the Juno cultivar significantly increased the in vitro digestibility of protein in the bread. The greatest increase in the effective protein (EP), chemical score (CS), protein digestibility-corrected amino acid score (PDCAAS) and essential amino acid index (EAAI) was achieved when the bread was enriched with flour from Polo cultivar. Wheat-rye flour enriching with lupin flour from the Juno, Polo, Legat and Markiz cultivars, intended for bread making, did not have a significant effect on the protein efficiency ratio (PER). The addition of lupin flour in the process of bread making resulted in enrichment of the final products in essential amino acids lysine and leucine, and non-essential amino acids asparagine and arginine. Protein of low-alkaloid cultivars of lupin Juno, Polo, Legat and Markiz can be a valuable component which increases the nutritional value of bread protein and for this reason it should be recommended for the use in baking.

\begin{abstract}
Acknowledgements
We would like to express our gratitude to Maciej Gawarecki for help in conducting the experiment and to Katarzyna Janowicz for collecting literature.

Project financially supported by Minister of Science and Higher Education in the range of the program entitled "Regional Initiative of Excellence" for the years 2019-2022, Project No. 010/RID/2018/19, amount of funding 12.000.000 PLN.
\end{abstract}

\section{References}

Abu-Ghoush M., Herald T.J., Dowell F., Xie F., Aramouni F.M. \& Madl R. (2008), Effect of preservatives addition on the shelf-life extensions and quality of flat bread as determined by near infrared spectroscopy and texture analysis, International Journal of Food Science and Technology, 43, pp. 357-364, DOI: 10.1111/j.1365-2621.2007.01594.x.

Agizzio A.P., Carvalho A.O., Ribeiro S.F., Machado O.L., Alves E.W., Okorokov L.A. \& Gomes V.M. (2003), A 2S albumin-homologous protein from passion fruit seeds inhibits 
the fungal growth and acidification of the medium by Fusarium oxysporum. Archives of Biochemistry and Biophysics, 416, pp. 188-195, DOI: 10.1016/S0003-9861(03)00313-8.

Agrawal S., Mane S., Majumdar D., Mazumdar A., Utikar R. \& Kale S. (2015), Lupins: Potential oral health supplement for management of diabetes, In: Proceedings of the XIV International Lupin Conference (edited by J. Capraro, M. Duranti. Ch. Magni, A. Scarafoni), pp. 83. Milan, Italy $21-26$ June 2016.

Al Omari D.Z., Abdul-Hussain S.S. \& Ajo R.Y. (2016), Germinated lupin (Lupinus albus) flour improves Arabic flat bread properties, Quality Assurance and Safety of Crops and Foods, 8, pp. 57-63, DOI: 10.3920/QAS2014.0441.

Anyango J.O., de Kock H.L., \& Taylor J.R. (2011), Impact of cowpea addition on the Protein Digestibility Corrected Amino Acid Score and other protein quality parameters of traditional African foods made from non-tannin and tannin sorghum, Food Chemistry, 12, pp. 775-780, DOI: 10.1016/j.foodchem.2010.06.094.

AOAC. (1995a), Protein (crude) in animal feed: Combustion method (990.03), In: Official Methods of Analysis 16th ed. Association of Official Analytical Chemists. Washington DC, USA.

AOAC. (1995b), Tryptophan in Foods and Food and Feed Ingredients, Ion Exchange Chromatography Method (988.15), In: Official Methods of Analysis 16th ed. Association of Official Analytical Chemists. Washington DC, USA.

Bähr M., Fechner A., Kiehntopf M., \& Jahreis G. (2015), Consuming a mixed diet enriched with lupin protein beneficially affects plasma lipids in hypercholesterolemic subjects: A randomized controlled trial, Clinical Nutrition, 34, pp. 7-14, DOI: 10.1016/j.cnlu.2014.03.008.

Bhat R., \& Karim A.A. (2009), Exploring the nutritional potential of wild and underutilized legumes, Comprehensive Reviews in Food Science and Food Safety, 8, pp. 305331, DOI: 10.1111/j.1541-4337.2009.0008.x.

Boye J., Wijesingha-Bettoni R. \& Burlingame B. (2012), Protein quality evaluation twenty years after the introduction of the protein digestibility corrected amino acid score method, British Journal of Nutrition, 108, pp. S183-S211, DOI: 10.1017/S0007114512002309.

Correia P., Gonzaga M., Batista L., Beirão-Costa L. \& Guiné R. (2015), Development and characterization of wheat bread with lupin flour, International Journal of Biological, Biomolecular, Agricultural, Food and Biotechnological Engineering, 9, pp. 923-927, DOI: scholar.waset.org/1999.1/10002521.

De Cortes-Sanchez M., Altares P., Pedrosa M.M., Burbano C., Cuadrado C., Goyoaga C., Muzquiz M., Jimenez-Martinez C. \& Davila-Ortiz G. (2005), Alkaloid variation during germination in different lupin species, Food Chemistry, 90, pp. 347-355, DOI: 10.1016/j.foodchem.2004.04.008.

Duranti M. (2006), Grain legume proteins and nutraceutical properties, Fitoterapia, 77, pp. 67-82, DOI: 10.1016/j.fitote.2005.11.008.

Erbaş M., Certel M. \& Uslu M.K. (2005), Some chemical properties of white lupin seeds (Lupinus albus L.), Food Chemistry, 89, pp. 341-345, DOI: $10.1016 /$ j.foodchem.2004.02.040.

Erbersdobler H.F., Barth C.A. \& Jahreis G. (2017a), Legumes in human nutrition. Nutrient content and protein quality of pulses, Ernahrungs Umschau International, 64, pp. 134-139, DOI: 10.4455/eu.2017.034

Erbersdobler H.F., Barth C.A. \& Jahreis G. (2017b), Legumes in human nutrition. Nutrient content and protein quality of pulses, Ernahrungs Umschau International, 64, pp. 140-144, DOI: 10.4455/eu.2017.034. 
EFSA European Food Safety Authority, (2005), Opinion of the Scientific Panel on Dietetic Products, Nutrition and Allergies on a request from the Commission related to the evaluation of lupin for labelling purposes, EFSA Journal, 302, pp. 1-11.

Gawęcki J. \& Jeszka J. (1986), Żywienie człowieka. Ćwiczenia, pp. 116. Warszawa, Poland: PWN.

Gresta F., Wink M., Prins U., Abberton M., Capraro J., Scarafoni A., \& Hill G. (2017), Lupins in European cropping systems, In: Legumes in Cropping Systems (edited by D. Murphy-Bokern F. L. Stoddard \& C. A. Watson). pp. 88-108. Wallingford, UK: CAB International.

Gularte M.A., Gómez, M. \& Rosell C.M. (2012), Impact of legume flours on quality and in vitro digestibility of starch and protein from gluten-free cakes, Food and Bioprocess Technology, 5, pp. 3142-3150, DOI:/ 10.1007/s11947-011-0642-3.

Hall R.S. \& Johnson, S.K. (2004), Sensory acceptability of foods containing Australian sweet lupin (Lupinus angustifolius) flour, Journal of Food Science, 69, pp. SNQ92-SNQ97, DOI: 10.1111/j.1365-2621.2004.tb15520.x.

Hryniewiecki L. (2007), Białka. In: Żywienie człowieka. Podstawy nauki o żywieniu, (edited by J. Gawęcki \& L. Hryniewiecki. pp. 176-197, Warszawa, Polska: Wydawnictwo Naukowe PWN.

Ikeda S. (1990), Dietary zinc and the zinc components in various foods subjected to in vitro enzymatic digestion, Journal of the Science of Food and Agriculture, 53, 229234, DOI: 10.1002/jsfa.2740530210.

Jarosz M., Charzewska J., Chwojnowska Z. \& Wajszczyk B. (2017), Białka. In: Normy żywienia dla populacji Polski, (edited by M. Jarosz). pp. 45. Warszawa, Polska. Wydawnictwo IŻं்.

Kohajdova Z., Karovicova J. \& Schmidt S. (2011), Lupin composition and possible use in bakery - a review, Czech Journal of. Food Science, 29, pp. 203-211, DOI: $10.17221 / 252 / 2009-C J F S$.

Lampart-Szczapa E., Korczak J., Nogala-Kalucka M. \& Zawirska-Wojtasiak R. (2003), Antioxidant properties of lupin seed products, Food Chemistry, 83, pp. 279-285, DOI: 10.1016/S0308-8146(03)00091-8.

Lee Y.P., Mori T.A., Sipsas S., Barden A., Puddey I.B., Burke V. \& Hodgson J. M. (2006), Lupin-enriched bread increases satiety and reduces energy intake acutely, The American Journal of Clinical Nutrition, 84, pp. 975-980, DOI: 10.1093/ajcn/84.5.975

Lucas M.M., Stoddard F.L., Annicchiarico P., Frias J., Martinez-Villaluenga C., Sussmann D., Duranti M., Seger A., Zander P.M. \& Pueyo J.J. (2015), The future of lupin as a protein crop in Europe, Frontiers in Plant Science, 6, Article 705, DOI: $10.3389 /$ fpls.2015.00705.

Martinez-Villaluenga C., Frias J. \& Vidal-Valverde C. (2006), Functional lupin seeds (Lupinus albus L. and Lupinus luteus L.) after extraction of $\alpha$-galactosides, Food Chemistry, 98, pp. 291-299, DOI: 10.1016/j.foodchem.2005.05.074.

Martinez-Villaluenga C., Zieliński H., Frias J., Piskuła M.K., Kozłowska H. \& VidalValverde C. (2009), Antioxidant capacity and polyphenolic content of high-protein lupin products, Food Chemistry, 112, pp. 84-88, DOI: 10.1016/j.foodchem.2008.05.040.

Mierlita D. (2015), The Effect of Lupine Seed in Broiler Diet on Animal Performance and Fatty Acids Profile of their Meat, Bulletin UASVM Animal Science and Biotechnologies, 72, pp. 188-193, DOI:10.15835/buasvmcn-asb:11375.

Monteiro M.R.P., Costa A.B.P., Campos S.F., Silva M.R., da Silva C.O., Martino H.S.D. \& Silvestre M.P.C. (2014), Evaluation of the chemical composition, protein quality 
and digestibility of lupin (Lupinus albus and Lupinus angustifolius), O Mundo da Saúde, São Paulo, 38, pp. 251-259, DOI: 10.15343/0104-7809.20143803251259.

Mubarak A.E. (2001), Chemical, nutritional and sensory properties of bread supplemented with lupin seed (Lupinus albus) products, Food/Nahrung, 45, pp. 241-245, DOI:/ 10.1002/1521-3803(20010801)45:4<241::AID-FOOD241>3.0.CO;2-Z.

Oser B.L. (1959), An integrated essential amino acid index for predicting biological value of proteins, In: Protein and amino acid nutrition (edited by A. A. Albanese), pp. 295311, New York, USA: Academic Press.

Raikos V., Neacsu M., Russell W. \& Duthie G. (2014) Comparative study of the functional properties of lupin, green pea, fava bean, hemp, and buckwheat flours as affected by pH, Food Science \& Nutrition, 2, pp. 802-810, DOI: 10.1002/fsn3.143.

Rakowska M., Szkiłłądziowa W. \& Kunachowicz H. (1978), Biologiczna wartość białka żywności, pp. 135-136. Warszawa, Polska: Wydawnictwa Naukowo-Techniczne.

Ruhterfurd S.M., Fanning A.C., Miller B. \& Moughan P.J. (2015), Protein digestibilitycorrected amino acid scores and digestible indispensable amino acid scores differentially describe protein quality in growing male rats, The Journal of Nutrition, 145, pp. 372-379, DOI: $10.3945 /$ jn.114.195438.

Rumiyati R., James A.P., \& Jayasena V. (2012), Effect of germination on the nutritional and protein profile of Australian sweet lupin (Lupinus angustifolius L.), Food and Nutrition Sciences, 3, pp. 621-626, DOI: 10.4236/fns.2012.35085.

Rumiyati R., James A.P., \& Jayasena V. (2015), Effects of lupin incorporation on the physical properties and stability of bioactive constituents in muffins, International Journal of Food Science \& Technology, 50, pp. 103-110, DOI:/ 10.1111/ijfs.12688.

Rybiński W., Święcicki W., Bocianowski J., Börner A., Starzycka-Korbas E. \& Starzycki M. (2018), Variability of fat content and fatty acids profiles in seeds of a Polish white lupin (Lupinus albus L.) collection, Genetic Resources and Crop Evolution, 65, pp. 417-431, DOI: 10.1007/s10722-017-0542-0.

Scarafoni A., Consonni A., Galbusera V., Negri A., Tedeschi G., Rasmussen P., Magni C. \& Duranti M. (2008), Identification and characterization of a Bowman-Birk inhibitor active towards trypsin but not chymotrypsin in Lupinus albus seeds, Phytochemistry, 69, pp. 1820-1825 DOI: 10.1016/j.phytochem.2008.03.023.

Schaafsma G. (2012), Advatages and limitations of the protein digestibility-corrected amino acid score (PDCAAS) as a method for evaluating protein quality in human diets, British Journal of Nutrition, 108, pp. S333-S336, DOI: 10.1017/S0007114512002541.

Schumacher H., Paulsen H.M., Gau A.E., Link W., Jürgens H.U., Sass O. \& Dieterich R. (2011), Seed protein amino acid composition of important local grain legumes Lupinus angustifolius L., Lupinus luteus L., Pisum sativum L. and Vicia faba L., Plant Breeding, 130, pp. 156-164, DOI: 10.1111/j.1439-0523.2010.01832.x.

Sedláková K., Straková E., Suchý P., Krejcarová J., \& Herzig I. (2016) Lupin as a perspective protein plant for animal and human nutrition - A review, Acta Veterinaria Brno, 85, pp. 165-175, DOI:10.2754/avb201685020165.

Siger A., Czubinski J., Kachlicki P., Dwiecki K., Lampart-Szczapa E., \& NogalaKalucka M. (2012), Antioxidant activity and phenolic content in three lupin species, Journal of Food Composition and Analysis, 25, pp. 190-197, DOI: 10.1016/j.jfca.2011.10.002.

Skibniewska K.A., Majewska K., Chwalisz K. \& Bieniaszewski T. (2003), Zastosowanie dodatku mąki różnych odmian łubinu żółtego (Lupinus luteus L.) do wypieku chleba, Zeszyty Problemowe Postępów Nauk Rolniczych, 495, pp. 415-423. 


\section{Food Technology}

Sujak A., Kotlarz A. \& Strobel W. (2006) Compositional and nutritional evaluation of several lupin seeds, Food Chemistry, 98, pp. 711-719, DOI: 10.1016/j.foodchem.2005.06.036.

Süssmann A.C., Loblay R., Soutter V. \& Swain,A. (2007), Lupin exposure study, Royal Prince Alfred Hospital - Allergy Unit, Available at: https://www.slhd.nsw.gov.au/rpa/allergy/research/students/2007/AnjaSussmann.pdf.

Tadele Y. (2015), White lupin (Lupinus albus) grain, a potential source of protein for ruminants: A review, Research Journal of Agriculture and Environmental Management, 4, pp. 180-188.

Tizazu H. \& Emire S.A. (2010), Chemical composition, physicochemical and functional properties of lupin (Lupinus albus) seeds grown in Ethiopia, African Journal of Food, Agriculture, Nutrition and Development, 10, pp. 3029-3046, DOI: 10.4314/ajfand.v10i8.60895.

Villarino C.B.J., Jayasena V., Coorey R., Chakrabarti-Bell S., Foley R., Fanning K. \& Johnson S. K. (2015a), The effects of lupin (Lupinus angustifolius) addition to wheat bread on its nutritional, phytochemical and bioactive composition and protein quality, Food Research International, 76, pp. 58-65, DOI: 10.1016/j.foodres.2014.11.046.

Villarino C.B.J., Jayasena V., Coorey R., Chakrabarti-Bell S. \& Johnson S.K. (2015b), The effects of Australian sweet lupin (ASL) variety on physical properties of flours and breads, LWT-Food Science and Technology, 60, pp. 435-443, DOI: 10.1016/j.lwt.2014.08.028.

Yeheis L., Kijora C., Melaku S., Girma A. \& Peters K.J. (2010), White lupin (Lupinus albus L.), the neglected multipurpose crop: its production and utilization in the mixed croplivestock farming system of Ethiopia, Livestock Research for Rural Development, 22(4), Article \#74, Available at: http://www.lrrd.org/lrrd22/4/yehe22074.htm.

Zielińska D., Frias J., Piskuła M.K., Kozłowska H., Zieliński H. \& Vidal-Valverde C. (2008), Evaluation of the antioxidant capaciity of lupin sprouts germinated in the presence of selenium, European Food Research and Technology, 227, pp. 1711-1720, DOI: 10.1007/s00217-008-0898-7.

Zraly Z., Pisarikova B., Trckova M., Herzig I., Juzl M. \& Simeonovova J. (2007), The effect of white lupine on the performance, health, carcass characteristics and meat quality of market pigs, Veterinarni Medicina, 52, pp. 29-41, DOI: 10.17221/2008-VETMED. 